\title{
PALEOZOIC LIMESTONES OF KITTATINNY VALLEY, NEW JERSEY *
}

\author{
BY HENRY B. KÜMMEI, AND STUART WELIER
}

(Read before the Society December 28, 1900)

\section{CONTENTS}

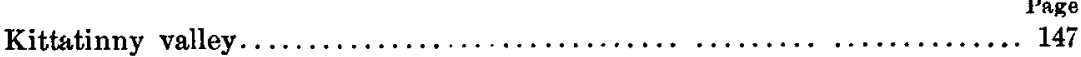

Hardiston quartzite......................................... 149

Relations and character............................... 149

Previous views...................................... 151

Kittatinny limestone.................................. 151

Stratigraphic and macroscopic characters.................... 151

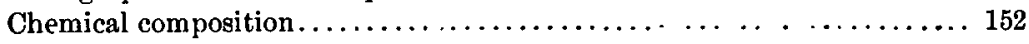

Fauna of the Kittatinny limestone..................... 152

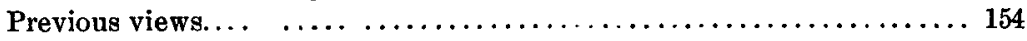

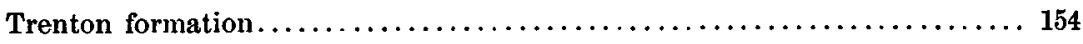

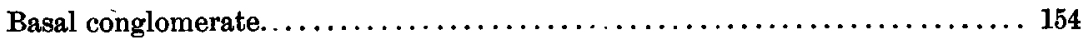

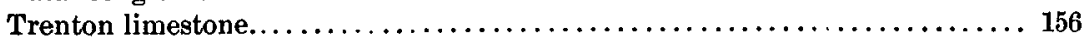

Character and thickness................................ 156

Chemical composition................................ 156

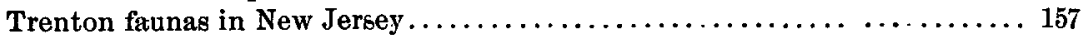

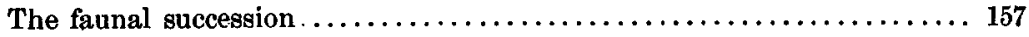

Correlation with New York Trenton...................... 159

Previous views..................................... 159

Structure........................................... 160

Folds and faults. .................................... 160

Cleavage........................................... 161

Conditions of sedimentation................................ 161

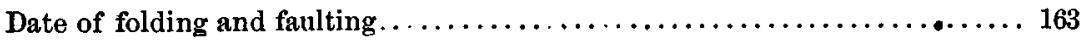

\section{Ki'TrATINNY VALLEY}

Kittatinny valley is the name given to that part of the Great Appalachian valley which traverses northern New Jersey. Its width varies from 10 to 13 miles, and it stretches from the Delaware river to the New York

* Published by permission of the State Geologist of New Jersey. 
state line. On the northwest it is bounded by the Kittatinny mountain, the crest of which is composed of hard Oneida conglomerate and sandstone. On the southeast lie the pre-Cambrian crystallines of the highlands, while the rocks of the valley are chiefly limestones and shales of

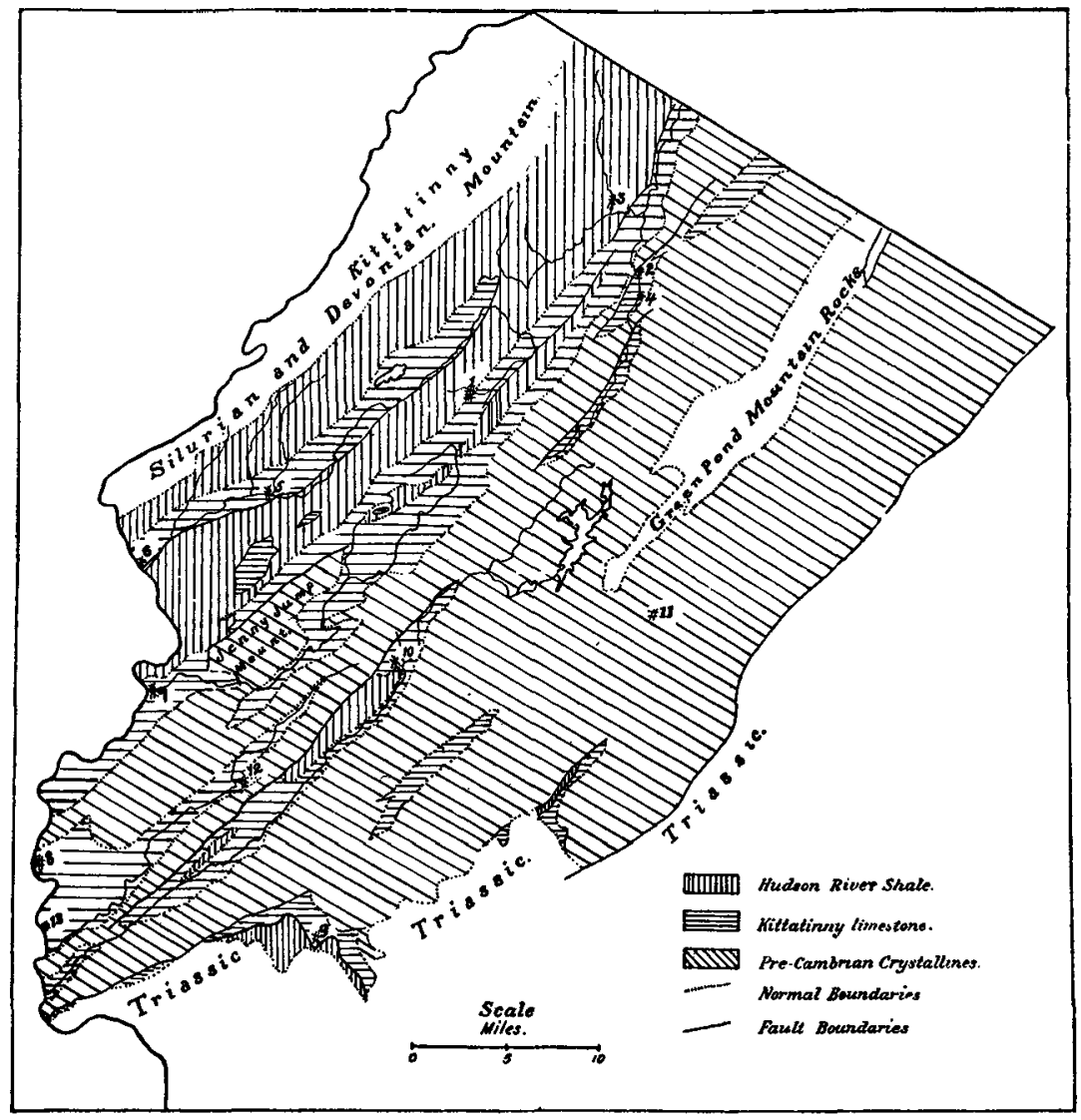

Figure 1.-Map of Northwestern New Jersey.

1. Newton. 2. Hamburg. 3. Deckertown. 4. Hardistonville. 5. Blairstown. 6. Columbia. 7. Belvidere. 8. Phillipsburg. 9. Hackettstown. 11. Dover. 12. Washington. 13. Garpentersville. The Hardiston quartzite forms a narrow outcrop along the normal contact of the Kittatinny limestone and the crystallines. The Trenton limestone forms a narrow outerop along the normal contact of the Kittatinny limestone and the Hudson River shale.

Cambrian and Ordovician age. In addition to this wide trough-like depression there are several long, narrow valleys within the highlands themselves, the rocks of which are of the same age as those of the Kittatinny valley. Small detached areas of the same formations occur along 
the eastern border of the highlands, and evidently underlie in part, at least, the Newark formation.

The general geological relations are shown in figure 1, which represents the northwestern part of the state, including the highlands, Kittatinny valley, and Kittatinny mountain. In the Kittatinny valley there is found the succession noted in the pages which follow.

\section{HaRdiston QUARTZITE}

\section{RELATIONS AND CHARACTER}

At the base of the limestone, resting upon the pre-Cambrian crystallines, there is a sandstone or quartzite of variable composition and thickness. It was described and named Hardistonville quartzite by Wolf and Brooks,* from the village of that name, near which there are good exposures. The shorter name used above, which is that of the township, seems preferable, however, and is here proposed.

The following description of this formation $\dagger$ for the Franklin Furnace area was given by Wolf and Brooks:

"When fresh the quartzite is usually bluish gray, weathering near the surface to a yellow or brown, often porous, limonitic rock. Frequently it contains considerable pyrite, and varies in coarseness from a fine conglomerate to a quartzite. A shaly phase is often present in the upper part of the bed, where it merges into the limestone. It is composed of large and small grains of clastic quartz, which are usually cemented by calcite, mixed with a fine aggregate of quartz. In many localities it is filled with fragments of clastic feldspar (microcline, etc.), and plates of light colored mica which are distinctly clastic, as seen in thin section. Where it occurs near the white limestone it frequently contains graphite . . . in round plates, often bent, and in thin section they show no evidence of having been formed in situ.

"The quartzite in many places becomes an arkose, and is then composed of quartz, feldspar, and mica, with fragments of granite."

These workers also found a few pebbles of white limestone imbedded in the quartzite at three localities.

Examination of the formation over a wider area has shown that it is even more variable in character than implied in the above extract. Some beds are composed of coarse rounded quartz grains, with some feldspar, the interstices being but slightly filled by any cementing material. In some sections the only approach to a quartzite is a coarse quartz sandstone or a fine grained sandy limestone, intercalated with beds of shale and dolomitic limestone. Elsewhere, as in the railroad

*U. S. Geol. Survey, 18th Annual Report of the Director, pt. ii, p. 442 et seq.

† Loc. cit, p. 442 . 
cut west of Hamburg station, a true quartzite occurs. Here a thin band of slightly arkose, vitreous quartzite is shown resting upon the granite.

Drift conceals all exposures for 10 or 12 feet, beyond which there are calcareous sandstones and sandy limestones for 45 or 50 feet. Fifty feet higher in the series a shaly limestone is exposed in an old quarry. Near Allamuche an arkose conglomerate occurs at the base of the formation. Pebbles 2 to 4 inches in diameter occur, although they are usually less than one inch. Pebbles of slate were noted in addition to the quartz, feldspar, mica, granite, and gneiss commonly present.

The quartzite is usually a blue-gray color when fresh, but some beds are a light yellow-brown, and others are nearly white. The arkose conglomerate layers vary considerably, owing to the varying shades of color of their constituents.

The thickness of the formation as given by Wolf and Brooks is from " 30 feet to a foot or less." In our wider studies it has frequently been found to have a much greater thickness. The conglomeratic phase is known to exceed 100 feet at a number of localities. In the railroad cuts at Washington, New Jersey, where the quartzite can be seen to rest on the slightly undulatory surface of a coarse grained pegmatitic granitoid-gneiss, it has a thickness of 100 feet, grading upward into a sandy limestone, of which 15 feet are exposed, and which is in turn succeeded by at least 10 or 15 feet of sandy shales. If these transition beds are to be included in the quartzite formation, its thickness here is at least 140 feet. Thin beds of shale, sandstone, and impure limestone have elsewhere been noted at about the same distance, 120-140 feet above the base of the formation. North of Clinton, on the southeastern flank of the highlands, the conglomeratic quartzite is over 185 feet thick, the top not being exposed and the transition beds not being included in the measurement.

The varying constitution, the local derivation of the material, and the great range in thickness indicate that the conglomerate is a shore deposit. Its increase in thickness toward the southeast locates the Cambrian land in that direction. Its occurrence on the southeastern flank of the highlands proves that the land lay farther east than the present highlands and probably even east of the present limits of the state.

Lower Cambrian trilobites have been found by Beecher, Foerste, and others in this formation near Franklin Furnace and Andover, and by Weller at various points from Franklin to Washington. They can be recognized only in the calcareous sandstone beds and here only in the weathered portion of the rock, from which the calcareous matter has been dissolved. This weathered rock is of a deep brown color, arenaceous and friable. It splits readily along the planes where the trilobite 
tests have been removed by solution during the process of weathering. A careful search in the fresh, unaffected portion of the rock failed to disclose any sign of fossil remains. That they are really present in abundance, however, is shown by the frequency of their occurrence in the weathered portions. We have found no fossils in the vitreous quartzites nor in the arkose beds.

\section{PREVIOUS VIEWS}

Professor Rogers* observed this formation at a few localities and called it number 1 of the Lower Secondary or Appalachian rocks.

Professor George $\mathrm{H}$. Cook $\uparrow$ correlated it with the Potsdam sandstone of New York on the basis of its position beneath the great limestone formation, all of which was believed to be the equivalent of the Calciferous sandstone of New York.

In 1890 F. L. Nason, in a paper presented to the Geological Society of America, announced the discovery by himself and Doctor Beecher of Lower Cambrian fossils in this quartzite.

Doctor Foerste $\$$ in 1893 added to the localities at which Cambrian fossils had been found and showed that the quartzite bed was more continuous than had been previously supposed.

C. D. Walcott $\S$ has shown that "the basal sandstones of Alabama, Tennessee, and Virginia (Chilhowee quartzite); Maryland, Pennsylvania, and New Jersey (the Reading quartzite); New York and Vermont (Bennington quartzite), were all deposited in Lower Cambrian time."

Wolf and Brooks || described the formation as it occurs near Franklin Furnace, New Jersey, and applied to it the geographical name "Hardistonville."

\section{Kit'TA'TINNY Limestone}

\section{STRA TIGRA PHIC AND MACROSCOPIC CHARACTERS}

Above the Hardiston quartzite and lying conformably on it is a great thickness of limestone, mostly dolomitic and unfossiliferous. Nearly all the limestone of both the Kittatinny valley and the allied highland valleys is included in this formation. It is somewhat variable in texture, bedding, and color, but these variations are not sufficiently constant to afford a basis of further subdivision. The color is usually blue or gray. Sometimes it is nearly black, and in places it has a pinkish tinge. Much of the formation occurs in massive beds, occasionally 3 or 4 feet thick.

* Description of the Geology of New Jersey, being a final report, Phila, 1840, pp. 45-47.

t Geology of New Jersey, 1868, p. 72.

¥ Foerste : Am. Jour. Sci., 3d series, vol, xlvi, 1893, pp. 435-444.

\& Walcott : Bulletin 134, U. S. Geol. Survey, 1896, p. 33,

fi) Wolf and Brooks, loc, cit. 
Contrasted with these there are several hundred feet of thin beds in the upper part of the formation in which bands of limestone an inch in thickness are separated by thin partings of greenish shale or by equally thin layers of sandstone. Some layers contain much chert, both in the form of nodular masses and as lenses a foot or less in thickness and several rods in diameter. Some beds are minutely crystalline, some of so dense and fine a texture that no grains nor crystals are visible macroscopically, and some of the lower beds are oolitic. At a number of points beds of almost pure limestone, alternating with the dolomitic layers, occur near the top of the formation as exposed. Owing to a slight unconformity, however, between this formation and the succeeding one, the top is a variable horizon.

The thickness of the Kittatinny limestone is probably about 2,700 to 3,000 feet, although owing to folds and faults no absolutely reliable estimates can be made; but the figures obtained are not discordant with estimates made in other states.

\section{CHEMICAL COMPOSITION}

Many analyses* of this limestone have been made by the New Jersey Geological Survey at various times, so that its chemical composition is well known. Nearly all the analyses, which are of specimens from widely scattered localities and different horizons, contain a large amount of magnesia, whence the name magnesian limestone, applied by Doctor Cook. Thirty-nine analyses showed the composition to vary within the following linits :

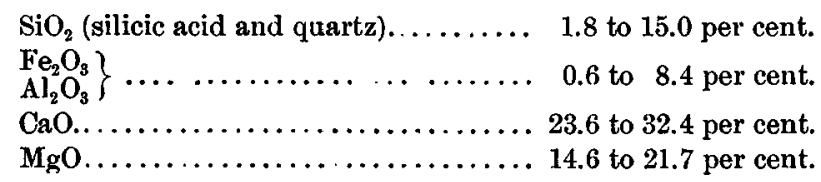

In the upper part of the formation a few thin layers of a purer limestone, with 90 per cent or more of carbonate of lime, alternate with the dolomite.

\section{FAUNA OF THE KITTATINNY LIMESTONE}

The calcareous sandstones forming the top of the Hardiston quartzite pass insensibly. into the lower arenaceous limestone of the Kittatinny formation, but the Lower Cambrian fauna of the quartzite has not been recognized in the Kittatinny limestone. The age of the beginning of the continuous Hardiston-Kittatinny sedimentation may be definitely fixed as Lower Cambrian.

\footnotetext{
*As the analyses were usually made for economic purposes the better layers were probably chosen and the markedly impure shaly or sandy layers rejected.
} 
In the midst of the limestone, fossils have been found in but four localities worthy of mention, although fragments of trilobites and brachiopods have been observed elsewhere. Just north of Blairstown a thin stratum was found containing a large number of individuals apparently belonging to but two species of trilobites. No entire specimens have been seen, both species being represented by cranidia, free cheeks, and pygidia. Our species is apparently undescribed and is probably referable to the genus Ptychoparia. The other, a much larger one, resembling the illustration of Bathyurus armatus, Billings, * but without the occipital spine, may be identified as Agraulos saratogensis Walc. The Upper Cambrian age of the bed containing these two trilobites is assured.

In O'Donnell and MacManniman's quarry, at Newton, a fauna of about ten species of brachiopods and trilobites was collected, which indicates theUpper Cambrian age of the enclosing sediments at that locality. Among the trilobites, a species of Dikelocephalus is by far the most abundant form, some fragments of which are of such a size as to indicate the presence of individuals having a breadth of head of several inches. A single broken cheek was found which seems to be indistinguishable from similar specimens in the Hardiston quartzite referred to the genus Olenellus. If additional specimens should confirm this identification, this occurrence of the two genera, Olenellus and Likelocephalus, associated together, would be a notable one.

At Carpentersville, south of Phillipsburg, in one of the outlying areas of the Kittatinny limestone, Cambrian trilobites were found, and the species Liostracus jerseyensis has been described $\uparrow$ from there, although it is quite probable that the generic reference is erroneous.

In the railroad cut at Columbia, on the Delaware branch of the New York, Susquehanna and Western railroad, a very different fauna was collected from a bed in the upper portion of the Kittatinny limestone. On the hillside above the cut, the overlying 'Trenton limestone is exposed, so that this fauna must occur within a few hundred feet of the summit of the formation. The fauna consists in large part of gasteropods, and the following preliminary identifications of the species have been made :

1. Syntrophia lateralis Whitf.?

2. Dalmanella sp. undet.

3. Platyceras sp. undet.

4. Metoptoma quebecensis Bill.?

5. Ophileta complanata Van.?
6. Ecculiomphalus sp. undet.

7. Raphistoma cf. $R$. staminea Hall.

8. Cyrtoceras cf. $C$. confertissimum Whitf.

9. Asaphus canalis Con.

10. Illænurus sp. undet. 
Although these identifications are but provisional, the whole complexion of the fauna is recognized as Calciferous, and on this evidence there can be no hesitation in correlating the upper portion of the Kittatinny limestone with the Calciferous. The evidence of the fossils therefore establishes the age of the Kittatinny limestone as including a part of the Lower Cambrian, the Middle and Upper Cambrian, and extending into the Calciferous. A study of the stratigraphy seems to indicate that there was no break in the sedimentation during this long period of time.

\section{PREVIOUS VIEWS}

Professor Rogers* included both the Kittatinny and the overlying Trenton limestone in his formation, number 2, of the Lower Secondary rocks. It is the magnesian or blue limestone of Professor Cook's $\dagger$ reports, and it was by him regarded as the equivalent of the Calciferous of New York. Prime $\ddagger$ concluded that the Magnesian limestones found in the extension of the Kittatinny valley into Pennsylvania " correspond in age to the Calciferous and Chazy epochs." The discoveries by Walcott. $\$$ Dwight, $\|$ and Dana of Lower Cambrian fossils in the lower portions of the same limestone in Pennsylvania and New York finally led to correct inferences as to the Cambrian and Lower Ordovician age of these rocks in New Jersey. Our determinations now confirm these inferences.

\section{Trenton Formation}

This formation consists of non-magnesian limestones and calcareous shales, with a local calcareous conglomerate of varying thickness at its base.

\section{Basal Conglomerate}

Resting on the slightly eroded surface of the Kittatinny limestone there is a basal conglomerate composed of pebbles of the underlying magnesian limestone and chert. It is not everywhere present in equal development, but it is practically coextensive with the Trenton limestone in New Jersey. Where observed it varies considerably in characterand thickness. It is sometimes merely a thin layer of small well rounded magnesian limestone pebbles in a purer limestone matrix, which occa-

\footnotetext{
* Rogers : Loc. cit.

$\dagger$ Cook : Loe. cit., p. 90.

$\ddagger$ Prime: Pennsylvania Second Geol. Survey, D 3, vol. i, p. 163.

\& Walcott : Loc. cit., p. 33.

\| Dwight : Am. Jour. Sei., 3d series, vol. xxxi, p. 125 et seq.; vol. xxxiv, p. 27 et seq. ; vol. $x \times x$ viii, p. 139.
} 
sionally contains Trenton fossils. It is sometimes represented only by a few scattered pebbles in the lower beds of the Trenton limestone. Elsewhere it may be 30,50 , or even 100 feet in thickness, and the waterworn fragments may exceed even 2 feet in diameter. In such instances lenses of lime "sandstone" occur in the conglomerate, together with thin layers of limestone bearing many segments of crinoid stems. In still other localities its constituents are large and angular, showing evidence of accumulation by waves in situ, with practically no transportation. On the weathered surface of such a bed the outlines of the fragments can not readily be seen, and it is not easily distinguished from a jointed and crushed bed of the Kittatinny limestone. Although the maximum observed thickness of this conglomerate is about 100 feet, with neither top nor base exposed, the usual thickness is only a few feet.

Good exposures are found (1) three-fourths of a mile east of Branchville, (2) just north of Newton, (3) at the northeast end of Jenny Jump mountain, near Southtown, (4) a mile east and southeast of Hope, (5) along the road one and a half miles northeast of Hope, and (6) along the railroad one-half mile north of Belvidere. It may be seen also at many other places along the line of the Trenton outcrop, which usually forms a narrow strip between the overlying slate and the Kittatinny limestone.

Walcott* has described certain conglomerates in the Cambrian limestones of Pennsylvania and elsewhere, which he has called intraformational, and which are defined as conglomerates "formed within a geologic formation of material derived from and deposited within that formation." Discontinuous beds of such conglomerates, some of a brecciated nature, have been observed at various points in the Kittatinny limestone, but the beds described above can not be put in that class for the following reasons :

First. The pebbles are limestone and chert, from the underlying dolomitic formation, which is not known to contain fossils of later age than the Calciferous. The matrix, on the contrary, is a much purer limestone and contains Trenton fossils (though not abundantly), and the associated limestone layers are very low in magnesia and contain a well marked Trenton fauna.

Second. The conglomerate rests unconformably on the underlying formation. So far as known the contact is exposed only at the Sarepta quarry, 3 miles northeast of Belvidere, where the conglomerate beds are not strictly conformable to the underlying layers, but dip northwestward at a slightly greater angle. The contact, although not sharply

* Bulletin 134, U. S. Geol. Survey, pp. 34-40.

XXIII-Burt. Grot. Soc. Aм., Vou. 12, 1900 
marked, is distinctly oblique to the underlying beds. The fragments in the lower layers of the conglomerate are coarse and angular, surrounded by a matrix of smaller fragments of the same sort, and have evidently undergone but little transportation and sorting. In the upper beds the fragments are smaller, better rounded, and the matrix carries crinoid stems and other obscure fossils. Above the conglomerate is found the typical Trenton limestone, through which are scattered occasional Kittatinny limestone pebbles. In other localities the dips of closely adjoining beds of Trenton and Kittatinny formations are not more discordant than might be expected in conformable formations which have been more or less closely folded.

\section{Trenton Limestone}

\section{CHARACTER AND THICKNESS}

The Trenton limestone proper rests either directly on the Kittatinny limestone or on the basal conglomerate. It is a dark blue or black, non-magnesian limestone, in massive beds, generally weathering into thin, knotty, irregular layers, a few of which are minutely crystalline. Some of these layers contain as high as 95 per cent carbonate of lime. Intercalated with the purer limestones are more shaly beds, and the whole formation grades into the overlying clayey, micaceous, slate, and sandstone formation through a series of calcareous shales, which are sparingly fossiliferous and commonly concealed by glacial drift or wash from the harder and topographically higher layers. It is this calcareous shale which forms the "cement rock" of the Lehigh and Phillipsburg Portland Cement regions. These calcareous shales, with the occasional thin bands of limestone which occur in them, are classed with the underlying fossiliferous limestones, rather than with the overlying argillaceous slates, although there is no sharp line of demarkation between them.

In the northern and central part of the Kittatinny valley the thickness of the Trenton is about 135 feet, but it increases toward the southwest, being 300 feet or more near the Delaware and apparently something more than that in the Lehigh region, Pennsylvania. The increase in thickness is due apparently to the increase in the thickness of the calcareous shales, the cement rock at the top, rather than of the purer, massive, fossiliferous limestones below.

\section{CHEMICAL COMPOSITION}

The Trenton limestones are not magnesian, as is the great mass of the Kittatinny formation. The purest layers contain 52 to 55 per cent of 
lime $(\mathrm{CaO})$ (out of a possible 56 per cent), less than 0.5 per cent of magnesia $(\mathrm{MgO})$, less than 1 per cent of iron and alumina, and 1 to 2 per cent of silica and other insoluble matter. The less pure limestones contain larger amounts of silica and of iron and alumina, a part of the silica being probably due to the presence of saind.

In the transition to the overlying Hudson River series, beds of exceedingly variable chemical composition may be found. The composition of the calcareous shales, so widely used for the manufacture of Portland cement, is approximately as follows:

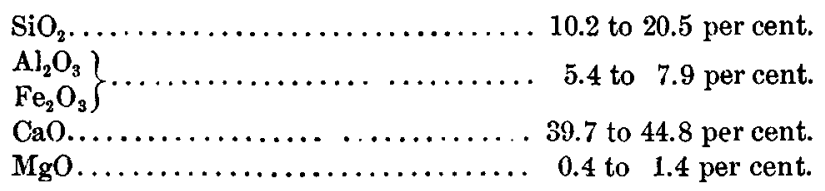

\section{Trenton Faunas in New Jursey}

THE FAUNAL SUCCESSION

Several distinct faunal zones have been recognized in this formation. Its outcrops, however, are so isolated and are usually so fully covered with débris that fossils can be collected only from loose fragments of the limestone on the surface. It is also rare to find more than a single faunal zone in any one outcrop. Under these circumstances the determination of the exact succession of the faunal zones is a problem of some difficulty. The investigation of the succession of these zones has been only just begun, and further study will undoubtedly add much to the results which can be announced at the present time. Enough has been determined, however, to suggest a general correlation between the Trenton formation as it occurs in New Jersey and New York.

The lowest definite horizon in the Trenton at which fossils have been found occurs at a locality a little over two miles southeast of Newton.* The basal conglomerate is but slightly developed, or is wanting at this locality, and in a bed lying but a few feet from the Kittatinny limestone the following fossils were collected:

1. Streptelasma profunda (H.).

2. Strophomena incurvata (Shep.).

3. Ctenodonta nasuia (H.).

4. Hormotoma gracilis (H.).

5. Orthoceras sp. undet.
6. Bumastus trenton ensis (Emm.).

7. Calymmene senaria Con.

8. Arges? sp. undet.

9. Leperditia fabulites (Con.).

* The exact locality is on the northwest slope of the 663-foot hill, about three-fourths of a mile north of the southwestern end of Iliff's pond. Sheet 1, New Jersey Topographical Atlas. 
Leperditia fabulites, a Black River species of ostracode, is the most abundant form, occurring in great numbers, almost to the exclusion of the other species. The complexion of the fauna, as a whole, is Black River, although none of the species are typically restricted to that horizon.

On the same hillside, lying stratigraphically 25 or more feet above the Leperditia horizon, but below it topographically, there is quite a different faunal zone with Parastrophia hemiplicata (Hall). This Parastrophia zone also occurs in an outcrop just north of Drake's pond, east of Newton, where the fauna is much better represented, and the following species were collected.:

1. Columnaria sp.

2. Lingulasma sp.

3. Plectambonites sericeus (Sow.).

4. Strophomena incurvata (Shep.).

5. Orthis tricenaria (Con.).

6. Dinorthis pectinella (Emm.).

7. Dalmanella testudinaria (Dal.) var.

8. Platystrophia biforata (Schl.).

9. Parastrophia hemiplicata (Hall).

10. Pterygometopus callicephalus (Hall).

11. Bumastus trentonensis (Emm.).

12. Isotelus gigas (De Kay).

13. Platymetopus trentonensis (Hall).

In his study of the 'Trenton faunas in New York, White* has found a Parastrophia zone to be quite constantly present at the top of the Black River horizon, and it is possible that the Parastrophia zone in New Jersey is a southern continuation of the same zone as it occurs in New York. Too much dependence, however, should not be placed upon the occurrence of Parastrophia hemiplicata, for the same species is known to occur even as high up as the Lorraine. Orthis tricenaria and Dinorthis pectinella, however, which occur in the fauna, are characteristically low Trenton forms, and Columnaria is usually considered as being typical of the Black River horizon.

Another faunal zone in the Trenton of New Jersey, which is apparently widespread, is characterized by a species of Receptaculites, probably $R$. occidentalis Salt. Because of the isolated nature of the outcrops, this Receptaculites zone has never been noticed in close association with any other zone, so that its exact position has not yet been definitely fixed, although it has been observed at many different localities. It is certainly in the lower portion of the formation and is probably beneath the Parastrophia zone. Streptelasma profunda and Columnaria usually occur associated with the Receptaculites.

The most prolific Trenton fauna in New Jersey, so far as observed, occurs on the summit of the hill northwest of Jacksonburg, a small village near Blairstown. This fauna occupies the highest position in

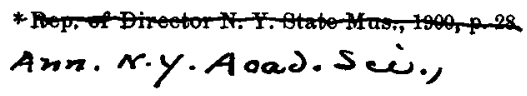


the formation of any yet noticed in New Jersey, and contains, in part, the following species:

1. Hindia parva (Ul.).

2. Streptelasma profunda (H.).

3. Orbiculoidea lamellosa (H.).

4. Schizocrania filosa (H.).

5. Dalmanella testudinaria (Dal.) var.

6. Plectambonites sericeus (Sow.).

7. Dinorthis pectinella (Emm.).

8. Strophomena incurvata (Shep.).

9. Rafinesquina allernata (Emm.).

10. Rhynchonella inæquivalvis (Castel.).

11. Rhynchotrema dentata (H.).

12. Zygospira recurvirostris (Н.).

13. Cuneamya truncatula (Ul.).

14. Whitella ventricosa (Н.).

15. Ctenodonta nasuta (H.).

16. Ctenodonia nitida (Ul.) ?

17. Ctenodonta levata (H.).

18. Clidophorus neglectus (H.).

19. Allodesma subellipticum (Ul.)?

20. Modiolopsis faba (Con.).

21. Bucania punctifrons Emm.

22. Tetranota bidorsata (H.).

23. Protowarthia cancellata (H.).

24. Conradella compressus (Con.)?
25. Archinacella patelliformis (H.).

26. Liospira subtilistriata (H.)

27. Eccyliomphalus trentonensis (H.).

28. Eccyliomphalis contiguus Ul. ?

29. Holopea obliqua H.?

30. Holopea supraplana U. and S. ?

31. Holopea symmetrica $\mathrm{H}$.

32. Lophospira obliqua U1.

33. Hormotoma gracilis (H.).

34. Pterotheca expansa (Emm.)?

35. Conularia trentonensis $\mathrm{H}$.

36. Harpina ottawensis (Bill.).

37. Trinucleus concentricus (Eaton).

38. Bronteus lunatus Bill.

39. Dalmanella achates Bill.

40. Pterygometopus callicephalus (Н.).

41. Proetus sp. cf. $P$. parviusculus $\mathrm{H}$.

42. Bumasius trentonensis (Emm.).

43. Calymmene senaria Con.

44. Isotelus gigas De Kay.

45. Ceraurus pleurexanthemus Green.

46. Platymetopus trentonensis (H.).

47. Odontopleura parvula (Walc.).

This fauna is apparently a well defined, typical Trenton fauna, and probably should be referred to about the middle Trenton.

\section{CORRELATION WITH NEW YORK TRENTON}

From the paleontologic evidence at hand, it can be quite definitely stated that the Trenton limestone in New Jersey represents the lower portion of the Trenton limestone of New York, including the Black River limestone, which is in reality nothing more than the basal portion of the Trenton. It is probable, also, that it does not represent the entire Trenton limestone as that formation occurs in its typical area in New York, but that the conditions for the deposition of the overlying shales and sandstone, which we call the Hudson River formation, were initiated earlier in this region than in the typical Trenton area.

\section{PREVIOUS VIEWS}

The Trenton age of the upper portion of the great limestone formation was recognized by Cook $*$ and termed by him the fossiliferous limestone. 
The determination of its age was in fact the basis on which the magnesian limestone and the "Potsdam" sandstone were referred to their respective horizons. Foerste's* later observations confirmed the correctness of the earlier determinations. Rogers observed the basal conglomerate as early as 1855 , at a point where it had been faulted against the crystallines. Brief mention of it has occasionally been made in the Geological Reports of the state geologist of New Jersey, but its stratigraphical importance has not previously been recognized.

\section{STRUCTURE}

FOLDS AND FAULTS

In the Kittatinny valley the rocks lie in several large open folds, the three main limestone areas forming anticlines, and the slate belts between them synclines, with axes trending northeasterly. Although in general the structure is thus very simple, in detail it is much more complex. Minor folds occur within the larger ones, more commonly in the overlying slate than in the limestone. These are frequently closely compressed, and vary in radius from a few feet to several rods, or even half a mile. The dips are usually steeper on the southeastern flank of the folds than on the northwestern, so that the axial planes must dip steeply to the northwest.

Thrust faults occur on the flanks of the folds in a number of cases, cutting out the narrow outcrop of Trenton limestone. The slate belt east of Newton is but half a syncline in its northern part, the westward half having been faulted off. The anticline of Kittatinny limestone along the Paulinskill has been faulted along its crest in such a way as to preserve a narrow strip of the Trenton limestone and conglomerate in the midst of the older formation.

West of Jenny Jump mountain-a huge island of gneiss in the midst of the Paleozoics, forming a detached portion of the highlands within the valley-faulting seems to have been more severe than elsewhere. A fracture along the western side of the mountain brings the Kittatinny and the Trenton limestones, as well as the Hudson River slate, successively against the gneiss. Elsewhere several small areas of the Kittatinny limestone are surrounded by the shale, and apparently rest on it, their position being probably due to thrust faults of considerable extent. At other points, also, the shale has been undoubtedly shoved over on the limestone. The fault planes are rarely exposed, and in many instances the direction and amount of the hade can not be determined. In the few cases observed northwest hades are more common than any other. 
In the inter-highland valleys, as was long since pointed out by Doctor Cook,* the folds are more compressed and are frequently overturned on the southeastern flank. In fact, so complex is the structure through close folding and faulting that it is next to impossible to work out the details. Still further to the southeast, along the border of the highlands, the exposures of the Paleozoic rocks are generally very meager and the structure complex. In a railroad cut near Clinton eighteen faults in the Hudson River slate were noted in a space of one hundred yards. They were at all angles, from nearly vertical planes to nearly horizontal thrusts.

\section{$C L E A V A G E$}

The more massive beds of the Kittatinny limestone show no signs of cleavage and usually no indications of shearing. Some of the thinner layers are obscurely cleaved, the cleavage planes usually dipping southeastward. The thin partings of shale which so frequently occur in some parts of the formation are very commonly sheared, showing that in the folding the layers slid past each other along their bedding planes.

The Trenton beds commonly show signs of shearing, even in the more massive layers. The shear planes usually dip steeply to the southeast. In many cases the fossils are distorted, and a marked fissility has been developed.

The Hudson River formation is usually every where so strongly cleaved, except in the case of the heavy sandstone layers, that the bedding is not readily distinguishable. Although the dip of the cleavage planes is most commonly to the southeast and crosses the bedding planes at constantly varying angles, yet this is not always the case. The cleavage is sometimes nearly horizontal and not infrequently to the northwest. In some exposures it is curved. Since the study of the Hudson River slates is far from complete, it is not possible to say whether there has been a continuation of the folding since the cleavage was formed, whereby the planes of cleavage have taken different attitudes, or whether in the folding the pressure was transmitted in such different directions that the cleavage was developed in planes at various angles and directions of dip.

\section{Conditions of Sedimentation}

The Hardiston quartzite indicates shore conditions near at hand. The varying lithological character of the formation, as well as its great range in thickness, often apparently within narrow geographical limits,indicates a wide range of conditions, such as would only prevail close to shore.

* Geology of New Jersey, 1868. 
The greater thickness of the formation at its southeastward exposures, as compared with the westward outerops, points to the existence of land to the southeast of the present highlands, conclusions which are in accord with those of workers in Pennsylvania and farther south.

During the formation of the Kittatinny limestones the waters were not deep, as wave marks occur at various horizons. The thin partings of shale or of sandstone in the limestone show that at intervals land derived mechanical sediments were present in sufficient amount to interrupt the formation of the dolomite; but in general the sea was remarkably free from sediment. The limestone exposed within the highlands or along their southeastern flank do not in themselves show a greater proximity to a shore than do those of Kittatinny valley, 20 miles or more to the northwest, and therefore that distance farther from the shoreline of that period. During this time the shore must have lain far east of its position during the formation of the Hardiston quartzite and a considerable distance east of the borders of New Jersey. In this, also, our studies are in accord with the conclusions of those who have studied these limestones farther south.

During the later stages of this period changes in the sea began, in consequence of which non-magnesian limestones alternated in deposition with the dolomites. Leslie * has shown that in southeastern Pennsylvania dolomitic and non-dolomitic beds alternate in sharply differentiated layers in the lower middle of the formation, due, he thinks, to alternating conditions of deposition; but there is nothing in the analyses of the New Jersey limestones to indicate that the changes began as early as in Pennsylvania.

The Trenton conglomerate and the slight unconformity between it and the Kittatinny limestone indicate an uplift of the sea bottom, erosion, and the prevalence of shore conditions in northern New Jersey and the neighboring region to the north. Our own studies have not extended north of New Jersey, but the occurrence of the Trenton conglomerate in southeastern New York is clear from the studies of others.

An exposure of it two and a half miles north of Newburg, New York, is pictured by Ries, $\uparrow$ although he does not mention it in his text. Concerning this outcrop Mr Gilbert Van Ingen, who took the photograph, writes : $\ddagger$

"The rock shown in the picture is a dark, impure limestone with many pebbles of the dolomitic lower Ordovician limestone. . . . The pebbles in the limestone are sometimes three inches in diameter."

* Second Pennsylvania Survey, M. M., pp. 360, 361.

$\dagger$ Report of the State Geologist of New York, 1895 , report on Orange county, pl. $\mathbf{x x x i}$.

$\ddagger$ Personal letters to the authors. 
Mr Van Ingen also reports outcrops of the conglomerate on the Jaycox farm, just north of Wappinger's falls. He says :

"Against this cliff (of dolomitic limestone) the Trenton was deposited. The line of contact is quite plainly seen and is rather irregular, with undercut projections. . . . The limestone here is partly a conglomerate of the dolomite pebbles and partly clear of these. . . . The peculiar feature of this locality is that the pebbles are not restricted to the lower layers, but occur at two or more levels, the intervening layers being either non-fossiliferous, dark; impure limestone or filled with the Solenopora. The true base of the limestone cannot be seen here, so that I was unable to determine whether it is conglomeratic or not. The pebbles are often large-five inches."

Dwight* also mentions a locality in the Wappinger valley, 2 miles southeast of Pleasant valley and 15 miles north of the above-mentioned locality, where the rock is "filled with limestone pebbles of various sizes and lighter in color than the mass." He states that many of these may have been organic, although no organic structure was visible. His words, however, describe exactly an exposure of the Trenton conglomerate. The occurrence of the conglomerate in Orange and Dutchess counties, New York, seems certain.

Although the conglomerate occurs beyond the limits of New Jersey to the northeast, it is, so far as our own brief observations and the writings of others go,absent to the southwest. In Pennsylvania and southward the Trenton beds follow those containing Calciferous and Chazy fossils with apparently no break in sedimentation. The region chiefly affected by the uplift, so far as data in hand show, was small as compared to the great extent of the Kittatinny limestone, and the movement gave rise, perhaps, to only a series of low, rocky islands and reefs, against which the waves beat and about which the conglomerate was formed; but the profound life change at this horizon, wherever the rocks of this age are exposed, even though the conglomerate and accompanying unconformity be not found, indicates something more than a local disturbance. The break in the record was long enough for the incursion of an abundant fauna of very different facies from that previously occupying the sea.

The passage from the Trenton limestone into the overlying shale and slate was due to changes prevailing along the entire A ppalachian valleychanges which Mr Weller's faunal studies show were inaugurated in New Jersey earlier than in the typical Trenton area in New York.

\section{Date of Folding and Faulting}

So far as observed, there are in New Jersey no data showing absolutely

*Am. Jour. Sci., 3d series, vol, xvii, p, 390. 
the date of the folding of these rocks. Slight unconformity between the Oneida conglomerate (Shawangunk grit) and the Hudson River shale is shown in the railroad cut at Otisville, New York, a few miles north of the New Jersey state line. This may mean that some folding took place at the close of the Ordovician. The greater disturbance, however, was undoubtedly at the close of the Paleozoic. Southeast of the highlands the Triassic rocks rest in part upon the eroded edges of these early Paleozoic formations. The profound faults of the former undoubtedly affect, in some instances, the underlying Paleozoics, but most of the faults in the Paleozoics along the borders of the Trias do not enter the latter, and are, therefore, older. If there was any disturbance in the Kittatinny Valley region during the Trias faulting, we have not been able to differentiate it from the earlier movements. 